\title{
ANALISIS USAHA KREATIF POTENSI LOKAL WONOSOBO MELALUI PRODUK COKLAT SARI CARICA DIENG
}

\author{
${ }^{1}$ Ulfi Meiyana, ${ }^{2}$ Rizki Ardiawan, ${ }^{3}$ Fiqoh Khoeriyah, ${ }^{4 *}$ Ahmad Khoiri \\ Universitas Sains Al Qur'an, Wonosobo, Jawa Tengah, Indonesia \\ Email:*akhoiri@unsiq.ac.id
}

Manuskrip: Juni -2021; Ditinjau: Juni -2021; Diterima: Juli -2021;

Online: Juli-2021; Diterbitkan: Juli-2021

\begin{abstract}
ABSTRAK
Pentingnya menggali usaha kreatif melalui COKSACAR (Coklat Sari Carica) yang dijadikan sebagai alternative solusi untuk mengatasi kejenuhan buah carica yang hanya dibuat sebagai makanan ringan seperti manisan dan kripik saja. Kegiatan Kewirausahaan dilakukan untuk: 1) Melatih kreativitas dan keterampilan dalam menciptakan inovasi baru yang berbahan baku Potensi lokal buah carica melalui kajian edupreneurscience (Sains dan ekonomi); 2) Menyajikan buah carica yang berbeda dari lainnya dengan tambahan variasi rasa, sehingga dapat menghilangkan kejenuhan cemilan buah yang biasanya; dan 3)Membuka peluang usaha baru untuk memperoleh laba yang nantinya bisa membuka lapangan pekerjaan. Metode penelitian melalui tahap persiapan produksi pada alat dan bahan; proses produksi dengan mengkaji edupreneurscience; dan pemasaran melalui analisis SWOT dan Mix Marketing 4P. Berdasarkan kegiatan kewirausahaan menunjukan bahwa: 1) Produk COKSACAR memanfaatkan potensi lokal Wonosobo dalam meningkatkan nilai jual buah carica serta dapat dikaji melalui viskositas sari carica dan potensi pengembangan usaha; 2) Terciptanya kegiatan kewirausahaan Produksi COKSACAR beraneka rasa meliputi rasa original, mocca, Green tea dan vanilla dengan rasa sari carica sehingga dapat menghilangkan kejenuhan dalam mengkonsumsi buah carica pada umumnya; dan 3)Menghasilkan pendapatan, peluang usaha baru serta mengurangi jumlah pengangguran karena pengembangan usaha yang berkelanjutan.
\end{abstract}

\section{Kata Kunci: Carica, Cokelat, Kewirausahaan, Potensi Lokal}

\section{PENDAHULUAN}

Kewirausahaan (Enterpreneur) dipengaruhi oleh persepsi terhadap kondisi lingkungan usaha yang berupa sumber daya alam, motivasi kerja dan kualitas pembinaan (Khoiri, Kahar, \& Indrawati, 2018). Penelitian yang berusaha untuk mengungkapkan konsep sains dan ekonomi (eduprenerscience) melalui kegiatan kewirausahaan pada usaha kreatif Coklat Sari Carica yang selanjutnya disebut COKSACAR. 
COKSACAR merupakan coklat yang dikombinasi dengan sari carica memunculkan rasa yang berbeda pada umumunya coklat ataupun buah carica yang monoton dibuat manisan saja. Potensi Lokal merupakan potensi yang dimiliki daerah itu sendiri (Fitria \& Wisudawati, 2018). Kabupaten Wonosobo yang merupakan penghasil dan pengolahan buah carica sehingga tak heran banyak industri berkembang mengolah buah carica menjadi berbagai macam produk yang memiliki nilai ekonomis tinggi seperti Carica in sirup dan manisan yang dijadikan oleh-oleh khas Wonosobo sebagai bagian dari potensi local (Edy Suprito, 2017). Saat ini perkembangan industri olahan carica di Kabupaten Wonosobo didukung oleh potensi tanaman carica yang semakin meningkat (Hasanah, 2010) dan (Fais, 2018).

Berdasarkan data Dinas Pertanian Kabupaten Wonosobo tahun 2011 jumlah carica di Dataran Tinggi Dieng meningkat yaitu mencapai 30.000 batang pohon dengan luas lahan tanam 115.77 ha. Dari hasil tersebut, olahan buah carica hanya diolah menjadi Carica in sirup yang semakin lama menimbulkan kejenuhan dan berkurang peminatnya. Permasalahan dapat teratasi dengan program yang akan dikembangkan untuk menghilangkan rasa jenuh dengan menciptakan produk cemilan Buah Carica dengan variasi berbagai rasa melalui kegiatan kewirausahaan.

Kegiatan kewirausahaan melalui tahapan persiapan, proses produksi dan pemasaran perlu dikaji secara sistematis serta membutuhkan keterampilan berwirausaha. Berdasarkan latar belakang masalah, tujuan kegiatan kewirausahaan untuk melatih kreativitas dan keterampilan dalam menciptakan inovasi baru yaitu pembuatan COKSACAR dengan cara menyajikan buah carica yang berbeda dari lainnya dengan tambahan variasi rasa, sehingga dapat menghilangkan kejenuhan cemilan buah yang biasanya hanya ada 1 rasa saja, Meningkatkan nilai jual buah carica agar menjadi sebuah terobosan baru dalam pembuatan makanan bervariasi, Membuka peluang usaha baru untuk memperoleh laba yang nantinya bisa membuka sebuah lapangan pekerjaan serta mengurangi pengangguran.

\section{METODE}

Program Kreativitas Mahasiswa Kewirausahaan (PKM-K) yang diharapkan adalah: 1) Terciptanya produk coklat dari buah carica yang dicampur dengan varian beraneka rasa sebagai alternatif makanan cemilan baru yang dapat dipasarkan dan di konsumsi oleh masyarakat dan 2) terciptanya peluang usaha mandiri bergerak di sektor olahan makanan ringan sebagai alternatif pilihan dengan harga terjangkau di kalangan masyarakat. Disajikan kajian potesi local carica dari hasil penelitian: adapun kegiatan PKM yang dilakukan disajikan dalam tabel 1. 
Tabel 1. Analisis Kegiatan Kewirausahaan COKSACAR

\begin{tabular}{|c|l|l|l|l|}
\hline No & $\begin{array}{c}\text { Kegiatan } \\
\text { Produksi } \\
\text { COKSACAR }\end{array}$ & \multicolumn{1}{|c|}{$\begin{array}{c}\text { Komponen } \\
\text { Kajian }\end{array}$} & \multicolumn{1}{|c|}{ Uraian } & Kajian Ilmiah \\
\hline 1 & $\begin{array}{l}\text { Persiapan } \\
\text { Produksi }\end{array}$ & $\begin{array}{l}\text { Analisis kesiapan } \\
\text { dan Analisis } \\
\text { SWOT }\end{array}$ & $\begin{array}{l}\text { - Menyediakan alat dan } \\
\text { bahan produksi }\end{array}$ & - \\
\hline 2 & $\begin{array}{l}\text { Proses } \\
\text { Produksi }\end{array}$ & $\begin{array}{l}\text { Menggunakan } \\
\text { langkah kegiatan }\end{array}$ & $\begin{array}{l}\text { Langkah kegiatan } \\
\text { berdasarkan proses } \\
\text { pembuatan COKSACAR }\end{array}$ & $\begin{array}{l}\text { Menganalisis } \\
\text { konsep } \\
\text { Viskositas pada } \\
\text { sarica }\end{array}$ \\
\hline 3 & Pemasaran & $\begin{array}{l}\text { Analisis Marketing } \\
\text { mix }\end{array}$ & $\begin{array}{l}\text { Menggunakan 4P yaitu } \\
\text { mengenai kebijakan produk, } \\
\text { harga, promosi dan distribusi }\end{array}$ & $\begin{array}{l}\text { Menganalisis } \\
\text { Potensi } \\
\text { pengembangan } \\
\text { berkelanjutan }\end{array}$ \\
\hline
\end{tabular}

Pelaksanaan program usaha pembuatan COKSACAR Khas Negri Atas Awan Beraneka Rasa ini terdiri dari tiga tahap yaitu: persiapan produksi dengan lokasi produksi di Dusun kemiri Desa kalibeber Kecamatan Mojotengah yang berada didaerah kampus UNSIQ Wonosobo dengan mempersiapkan alat dan bahan produksi serta pemasaran dengan cara online, jejaring social serta perluasan mitra. Tahapan produksi COKSACAR disajikan dalam gambar 1.

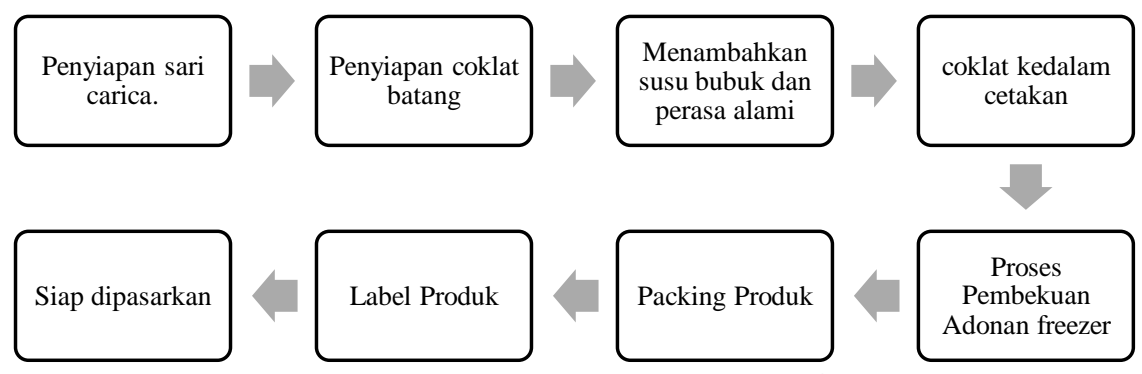

Gambar 1. Proses Produksi COKSACAR

Setelah proses pengemasan selesai, langkah selanjutnya adalah pemasaran. Target konsumen adalah masyarakat dari berbagai kalangan, baik masyarakat ekonomi atas maupun menengah ke bawah karena harganya terjangkau. Usaha COKSACAR bekerjasama dengan toko oleh-oleh khas Wonosobo karena carica adalah buah khas Wonosobo, supermarket, dan toko-toko disekitarnya maupun wilayah lain yang mempunyai potensi penjualan sebagai pusat-pusat pemasaran. Selain itu juga menggunakan jejaring sosial sehingga usaha COKSACAR Khas Negri Atas Awan cepat dikenal. Perolehan buah carica di peroleh secara langsung dari petani carica. Sedangkan perolehan bahan baku yang lainnya diperoleh di Pasar Induk Wonosobo serta manajemen usaha dilakukan berdasarkan komponen analisis SWOT.

\section{HASIL DAN PEMBAHASAN}

Berdasarkan analisis SWOT menunjukan bahwa produk COKSACAR terdapat peluang pasar pada kelebihan dari coklat carica mampu bersaing dengan produk keripik atau yang sejenisnya, untuk lebih jelasnya disajikan dalam tabel 2. 
Tabel 2. Analisis SWOT Usaha COKSACAR

\begin{tabular}{|c|c|c|}
\hline \multicolumn{3}{|c|}{ Analisis SWOT } \\
\hline 1 & $\begin{array}{ll}\text { Strength } \\
\text { - } \quad \text { Harga relatif terjangkau } \\
\text { - } \quad \text { Produk menarik sehingga disukai } \\
\text { semua kalangan, } \\
\text { - } \quad \text { Belum ada produk yang serupa, } \\
\text { - } \quad \text { Rasa khas yang susah ditemukan, } \\
\text { - } \quad \text { Bahan baku produk melimpah di } \\
\quad \text { kabupaten wonosobo saja. }\end{array}$ & $\begin{array}{l}\text { 2. } \\
\text { Weakness } \\
\text { - } \text { Produk kurang bertahan terlalu lama. } \\
\text { - } \text { Rasa coklat dalam COKSACAR masih } \\
\text { mendominasi meskipun sari carica sudah } \\
\quad \text { terasa. }\end{array}$ \\
\hline 3 & $\begin{array}{l}\text { Opportunity } \\
\text { - } \quad \text { Melayani jual beli online. } \\
\text { - } \\
\text { Belum ada yang memulai bisnis } \\
\text { serupa. } \\
\text { - } \\
\text { - } \\
\text { COKenerima PO } \\
\text { dengan coklat pada umumnya. }\end{array}$ & $\begin{array}{ll}\text { 4. } & \text { Treat } \\
\text { - } & \text { Adanya rasa jenuh dikalangan konsumen } \\
& \text { dalam mengkonsumsi coklat. }\end{array}$ \\
\hline
\end{tabular}

Analisis SWOT digunakan utuk mengidentifikasi komponen-komponen SW-O-T lebih efektif dibandigkan dengan yang lain (Permadi, 2015). Kelebihan itu dapat dilihat dari berbagai segi. Dalam hal rasa, memiliki aroma, rasa yang berbeda dengan coklat pada umumnya. Dari segi kesehatan jelas bahwa coklat ini memiliki kandungan nutrisi cukup lengkap yang diperlukan bagi tubuh manusia, salah satunya yaitu kandungan Vitamin $\mathrm{C}$ dan karbohidrat yang tinggi. Dalam hal harga lebih terjangkau masyarakat karena dengan bahan dasar yang melimpah dan mudah didapat dengan harga yang murah menjadikan biaya produksi coklat ini lebih rendah sehingga harga jual kepada masyarakat juga rendah dibanding produk coklat lain dan menjadikan daya tarik masyarakat untuk membelinya.

Selanjutnya dianalisis berdasarkan viskositas pada kajian sains dan analisis pengembangan usaha pada ilmu ekonomi.

\section{Analisis Viskositas Sari Carica}

Viskositas adalah ukuran yang menyatakan kekentalan suatu cairan atau fluida untuk mengalir di bawah pengaruh tegangan geser (Khoiri et al., 2018). Persamaan yang digunakan untuk menentukan viskositas:

$$
\eta=\left(0.0026 t-\frac{1.175}{t}\right)-\left(\rho_{\text {cair }} \rho_{\text {udara }}\right)
$$

Keterangan $: \eta=$ viskositas mutlak (poise) dan $\mathrm{t}=$ waktu (detik)

Berdasarkan hasil kegiatan proses produksi COKSACAR, terdapat proses buah carica yang diblender supaya terdapat sari caricanya, saat inilah koefisien viskositas dan residu zat cair dapat diperhitungkan. Adapun hasil perhitungan viskositas disajikan dalam tabel 3.

Tabel 3. Hasil pengukuran Viskositas pada Sari Carica

\begin{tabular}{|c|c|c|c|}
\hline Besaran & Tanpa Filter & $\begin{array}{c}\text { Media Kain } \\
\text { Halus }\end{array}$ & $\begin{array}{c}\text { Media Kain } \\
\text { Parasit }\end{array}$ \\
\hline Residu Sari Carica (cc) & 0 & 1500 & 2500 \\
\hline Koefisien Viskositas (Pas) & 0,0112 & 0,0054 & 0,0026 \\
\hline
\end{tabular}

Berdasarkan tabel 3 bahwa sifat zat cair adalah memiliki koefisien kekentalan (viskositas) yang berbeda-beda. Viskositas( $\eta$ ) berhubungan dengan gaya gesekan antara bagian atau lapisan cairan ynag bergerak satu terhadap lainnya. Fluida yang 
berbeda memiliki besar viskositas yang berbeda. Hasil penelitian menunjukkan viskositas $(\eta)$ sari carica tanpa filter, sari carica media kain halus dan kain parasit berturut-turut 0,0112 Pas, 0,0054 Pas, dan 0,0026 Pas. Viskositas sari carica tanpa filter lebih tinggi atau dapat dikatakan lebih kental karena kekentalan fluida direpresentasikan oleh koefisien viskositas.

Kajian viskositas dapat dijadikan referensi dalam pencampuran adonan takaran sari carica, coklat yang sudah dilelehkan dan telah dicampuri susu bubuk, sehingga dalam proses produksi serta keuntungan yang didapatkan setelah penjualan dapat lebih maksimal. Jika adonan dan takaran yang tidak tepat dapat menghambat proses produksi COKSACAR.

\section{Analisis Potensi Pengembangan Usaha}

Berdasarkan hasil penelitian suatu negara akan menjadi makmur apabila mempunyai enterpreneur sedikitnya $2 \%$ dari jumlah penduduk. Indonesia diperkirakan hanya 400.000 orang yang tercatat menjadi pelaku usaha mandiri atau sekitar 0,18\% tercatat Agustus 2016 sampai Februari 2017 pengangguran terdidik naik sebesar $9,88 \%$ dikuatkan oleh BPS bahwa tingkat pengangguran terbuka Indonesia pada Februari 2017 sebesar 5,33\% atau 7,01 juta jiwa dari total 131,55 juta orang angkatan kerja. Realita ini menjadi faktor penting potensi pengembangan usaha COKSACAR yang menjanjikan perlu didesain semaksimal mungkin.

Potensi pengembangan usaha oleh (Khoiri et al., 2018) menyatakan kewirausahaan sebagai kesungguhan untuk menciptakan sesuatu yang baru, membuat sesuatu yang berbeda, dengan maksud untuk meningkatkan kesejahteraan individu serta memberikan nilai tambah bagi masyarakat selaras dengan tujuan kegiatan PKM-K pada produksi COKSACAR. Selanjutnya Ketercapain Target Luaran usaha dilihat pada tabel 4.

Tabel 4. Target Luaran Usaha COKSACAR

\begin{tabular}{|c|c|c|c|}
\hline \multirow{2}{*}{ No } & Target & \multicolumn{2}{c|}{ Ketercapaian Target 100\% } \\
\cline { 2 - 4 } & Survey Pasar & $100 \%$ & Terlaksana \\
\hline $\mathbf{1 .}$ & Pemenuhan Alat dan Bahan & $90 \%$ & - \\
\hline $\mathbf{2 .}$ & Tempat Produksi & $100 \%$ & - \\
\hline $\mathbf{3 .}$ & Pelaksanaan Produksi & $100 \%$ & - \\
\hline $\mathbf{4 .}$ & Pemasaran & $67 \%$ & $33 \%$ \\
\hline $\mathbf{5 .}$ & a. Sosial Media & $90 \%$ & $10 \%$ \\
\hline & b. Brosur, Banner & $80 \%$ & $20 \%$ \\
& c. Perluasan ke Kota lain & $30 \%$ & $70 \%$ \\
\hline $\mathbf{6 .}$ & Laporan & $100 \%$ & - \\
\hline & Tingkat Pencapaian & $92 \%$ & $8 \%$ \\
\hline
\end{tabular}

Berdasarkan tabel 4 tingkat ketercapaian yang belum terlaksana sebesar $8 \%$, dengan diperolehnya dana dari berbagai pihak sebesar 2.500.000,- (dua juta lima ratus ribu rupiah) sehingga dapat terpenuhi alat yang belum tersedia seperti alat pencair coklat, membeli cetakan dengan berbagai bentuk. Produksi COKSACAR dalam skala besar dan varian banyak dapat dilakukan. Selain itu pemasaran yang belum terlaksana untuk cetak banner, brosur skala besar serta online market supaya lebih maksimal kembali. 
Untuk mengembangkan suatu usaha di perlukan strategi yang bagus untuk mencapai sasaran jangka panjang. Strategi bisnis dapat termasuk perluasan geografis, diversifikasi, akuisisi, pengembangan produk, penetrasi pasar, pengurangan bisnis, divestasi, likuidasi dan usaha patungan. Produksi COKSACAR sangat prospek untuk dikembangkan secara berkelanjutan karena bahan baku yang tersebar di area dataran tinggi Dieng Wonosobo sangat unik dan tidak semua daerah terdapat buah carica. Berkaitan potensi lokal, Kementerian Kebudayaan dan Pariwisata RI Tahun 2011 mengemukakan bahwa keunggulan lokal merupakan jawaban kreatif terhadap situasi geografis, politis, historis, situasional yang bersifat lokal dan mengandung sikap, pandangan, dan kemampuan suatu masyarakat di dalam mengelola lingkungan rohani dan jasmani dimana ia berada, sehingga produksi COKSACAR dengan varian rasa coklat yang berbeda menjadikan ciri khas Negeri atas awan yang tentunya tidak ada didaerah lain.

COKSACAR sebuah usaha yang mampu mempertahankan keunggulan kompetitif potensi lokal karena hanya satu satunya di Kabupaten Wonosobo, terbukti dari hasil penelusuran google atau online lainnya belum terdapat coklat sari carica, namun sebuah usaha tidaklah cukup untuk memiliki keunggulan kompetitif seperti ini saja.

(Harsi, 2011) Capaian target usaha untuk mencapai keunggulan kompetitif yang berkelanjutan (sustainable competitive advantage) yaitu: (1) secara terus menerus beradaptasi dengan tren pasar karena COKSACAR masih bersifat lokal perlu pemasaran online secara luas, persiapan SDM dalam usaha yang diupdate secara keilmuan, jejaring mitra yang berkelanjutan untuk memperlancar usaha, serta (2) secara efektif memformulasikan, mengimplementasi dan mengevaluasi strategi yang mengambil keuntungan dari faktor-faktor usaha COKSACAR.

\section{Analisis Pemasaran}

Usaha pembuatan coklat carica menggunakan analisis Marketing Mix (bauran pemasaran) 4P yaitu mengenai kebijakan produk, harga, promosi dan distribusi:

Kebijakan Produk berupa coklat yang mengandung energi sebesar 472 kilokalori, protein 2 gram, karbohidrat 62,7 gram, lemak 29,8 gram, kalsium 63 miligram, fosfor 287 miligram, dan zat besi 3 miligram, vitamin A sebanyak $30 \mathrm{IU}$, vitamin B1 0,03 miligram dan vitamin C 0 miligram. Dengan rasa, aroma, serta warna yang hampir sama dari coklat yang lain, coklat carica mempunyai keunggulan lebih mengandung Vitamin $\mathrm{C}$.

Kebijakan harga berbasis laba rugi, sehingga harga yang diberikan kepada pelanggan yaitu sebesar Rp 20.000,- per bungkus berdasarkan perhitungan ekonomi akuntan, harga ini lebih rendah dibanding harga pesaing yang biasanya menawarkan harga antara Rp 25.000 sampai Rp. 40.000,00 per bungkus.

Penjualan COKSACAR Khas Negeri Atas Awan cukup membuat masyarakat tertarik untuk mencoba produk baru dengan menggunakan bahan yang tidak asing di lidah masyarakat Wonosobo. Produksi COKSACAR banyak mengalami kenaikan terutama di bulan Ramadhan. Berikut ini grafik produksi COKSACAR pada gambar 1. 


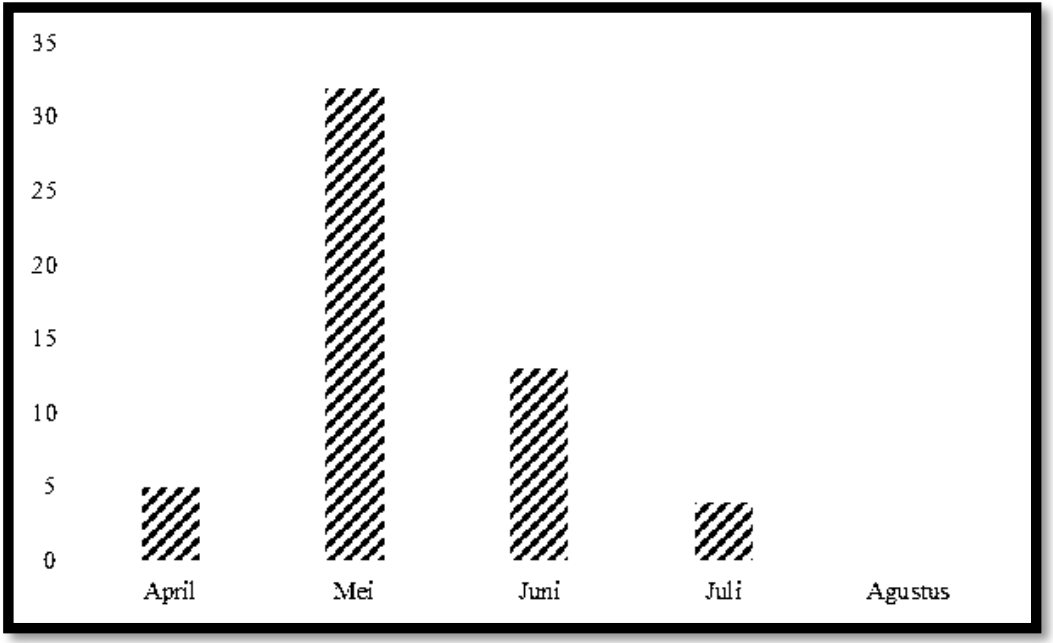

Gambar 2. Hasil Penjualan Produksi COKSAKAR

Varian rasa yang digemari oleh para konsumen adalah original. Menurut konsumen COKSACAR original lebih memiliki ciri khas rasa buah carica, "Saya lebih menyukai yang original, soalnya rasa carica lebih bisa dirasakan ciri khasnya" ujar ibu Halimah salah satu pembeli.

Produk COKSACAR sangat diminati di pasaran berdasarkan gambar (1) sesuai dengan lidah semua kalangan masyarakat sekarang yang sangat gemar makan coklat. Produk COKSACAR bisa bersaing dengan produk sejenis karena dibuat dengan bahan berkualitas tinggi dan sehat alami. Terlebih lagi bahwa melihat hasil penjualan bulan Juli yang sangat memuaskan bahkan pada bulan bulan tertentu daya minat beli COKSACAR melonjak cukup tinggi. Melalui kegiatan produksi COKSACAR menumbuhkan kemampuan wirausaha serta keterampilan dalam melakukan produksi serta pemasaran seperti industri di UMKM Carica pada umumnya (Mudrikah, 2013).

Bentuk promosi diantaranya dengan pamflet, brosur dan media promosi lainnya dengan media sosial online seperti Wahatsapp, Instagram dan Facebook. Di samping itu, penawaran di warung-warung, toko, koperasi, mini market untuk kerjasama secara berkelanjutan. Distribusi hasil produksi kepada para konsumen dilakukan secara langsung ditempat usaha maupun secara tidak langsung yaitu dengan menawarkan kerja sama ke berbagai toko maupun minimarket. Selanjutnya perluasan pemasaran COKSACAR bekerja sama dengan koperasi (KUB Annisa), minimarket (Sakinah), kantin kampus dan warung. Kegiatan usaha dikuatkan oleh penelitian (Nafingah et al., 2018) dalam implementasi program dan meningkatnnya UMKM dengan cara kerjasama dengan mitra ataupun komunitas, namun masih terdapat keterbatasan pada kegiatan kewirausahaan terutama pemasaran lintas daerah karena sifat promosi masih berdasarkan kebutuhan pembeli saja dikuatkan oleh penelitian (Dewi, 2009).

Berdasarkan analisis hasil kajian kewirausahaan sangat berpotensi untuk dikembangkan secara berkelanjutan usaha COKSACAR karena rasa coklat yang khas caricanya menjadi sensasi baru dan trend kekinian serta dapat mengurangi 
kejenuhan rasa buah carica yang didapatkan dari produk yang telah ada seperti manisan in syrup, kripik saja, invovasi baru usaha COKSACAR ini dijadikan peluang usaha yang sangat menjanjikan, meskipun terdapat hambatan dan permasalahan yang dianalisis SWOT sebagai langkah dalam mengembangkan potensi usaha berkelanjutan.

\section{KESIMPULAN}

Berdasarkan hasil dan pembahasan bahwa analisis kewirausahaan potensi lokal buah carica bahwa: 1) Produk COKSACAR dengan memanfaatkan potensi lokal Wonosobo dapat meningkatkan nilai jual buah carica yang dijadikan inovasi baru dalam pengolahan buah carica melalui kajian viskositas pada sari carica dan kajian ekonomi pada potensi pengembangan usaha; 2) Terciptanya kegiatan kewirausahaan Produksi COKSACAR khas Negeri atas awan Dieng Wonosobo yang beraneka rasa meliputi rasa original, mocca, Green tea dan vanilla yang khas dengan rasa sari carica sehingga dapat menghilangkan kejenuhan dalam mengkonsumsi buah carica pada umumnya; 3) Menghasilkan pendapatan dari produksi COKSACAR sebagai langkah awal membuka peluang usaha olahan makanan yang menjanjikan; Membuka lapangan pekerjaan pada olahan makanan berupa produksi COKSACAR dengan harga terjangkau di kalangan masyarakat, sehingga dapat mengurangi jumlah pengangguran.

\section{UCAPAN TERIMAKASIH}

Ucapan terimakasih kami sampaikan kepada Program Kreativitas Mahasiswa (PKM) Dirjen Belmawa Dikti Tahun 2019 atas Bantuan Dana yang telah diberikan kepada kami tim PKM-K dari Universitas Sains Al Quran Jawa Tengah di Wonosobo serta kepada tim pembimbing dan civitas akademika yang selalu mensuport demi kesuksesan PKM kami, sehingga berkesempatan dan lolos PIMNAS ke 32 di Universitas Udayana Bali.

\section{DAFTAR PUSTAKA}

Dewi, S. K. 2009. Analisis Strategi Pengembangan Usaha Industri Kecil Olahan Carica. Skripsi. Fakultas Ekonomi dan Manajemen IPB Bogor.

Efendi, F.Y. 2018. Analisis Kelayakan Industri Rumah Tangga Manisan Carica Di Kecamatan Kejajar Kabupaten Wonosobo. Skripsi. Fakultas Pertanian Universitas Muhammadiyah Yogyakarta.

Fitria, M., \& Wisudawati, A. W. 2018. The Development of Ethnoscience-Based Chemical Enrichment Book as a Science Literacy. International Journal of Chemistry Education Research. 2(1): 50-59.

Harsi, R. 2011. Strategi Pengembangan Industri Kecil Carica Untuk Meningkatkan Pendapatan Pengrajin di Kabupaten Wonosobo Tahun 2010. Skripsi. Universitas Sebelas Maret Surakarta.

Hasanah, U. 2010. Proses Produksi Manisan Carica. Tugas Akhir. Universitas Sebelas Maret Surakarta.

Khoiri, A., Kahar, M. S., \& Indrawati, R. T. 2018. Ethnoscience Approach in 
Cooperative Academic Education Programs (COOP). Journal of Physics: Conference Series. 1114(1): 1-7.

Mudrikah, A. Sucihatiningsih. 2013. Strategi Pengembangan Usaha Industri Kecil Olahan Carica Ukm Gemilang Di Kabupaten Wonosobo. Economic Education Analysis Journal. 2(1): 18-23.

Nafingah, L., Irhandayaningsih, A. 2018. Implementasi Program Perpuseru Dan Peranannya Dalam Kejajar Kabupaten Wonosobo. Skripsi. Universitas Diponegoro Semarang.

Permadi, A. 2015. Strategi Pengembangan Industri Kecil Carica. Jejak: Journal of Economics and Policy. 8(1): 38-44.

Supriyo, E, Wisnu Broto, Retno Hartati. 2017. UKM Carica Dieng Perluas Pangsa Pasar Ke Eropa. Seminar Nasional 6th UNS SME's SUMMIT \& Awards 2017 Peningkatan Daya Saing UMKM Berbasis Ekonomi Kreatif dalam Era Masyarakat Ekonomi ASEAN. 3 April 2017: 282-290. 